OPEN ACCESS

Edited by:

Horacio Naveira,

University of a Coruña, Spain

Reviewed by:

Wolfgang J. Miller,

Medical University of Vienna, Austria

Varvara Yu. Vedenina,

Institute for Information Transmission

Problems (RAS), Russia

*Correspondence:

José L. Bella

bella@uam.es

Specialty section:

This article was submitted to Evolutionary and Population Genetics,

a section of the journal

Frontiers in Genetics

Received: 31 August 2018 Accepted: 19 November 2018 Published: 04 December 2018

Citation:

Martínez-Rodríguez P and Bella JL

(2018) Chorthippus parallelus and Wolbachia: Overlapping Orthopteroid and Bacterial Hybrid Zones.

Front. Genet. 9:604.

doi: 10.3389/fgene.2018.00604

\section{Chorthippus parallelus and Wolbachia: Overlapping Orthopteroid and Bacterial Hybrid Zones}

\author{
Paloma Martínez-Rodríguez and José L. Bella* \\ Departamento de Biología (Genética), Facultad de Ciencias, Universidad Autónoma de Madrid, Madrid, Spain
}

Wolbachia is a well-known endosymbiotic, strictly cytoplasmic bacterium. It establishes complex cytonuclear relations that are not necessarily deleterious to its host, but that often result in reproductive alterations favoring bacterial transmission. Among these alterations, a common one is the cytoplasmic incompatibility $(\mathrm{Cl})$ that reduces the number of descendants in certain crosses between infected and non-infected individuals. This $\mathrm{Cl}$ induced by Wolbachia appears in the hybrid zone that the grasshoppers Chorthippus parallelus parallelus (Cpp) and C. p. erythropus (Cpe) form in the Pyrenees: a reputed model in evolutionary biology. However, this cytonuclear incompatibility is the result of sophisticated processes of the co-divergence of the genomes of the bacterial strains and the host after generations of selection and coevolution. Here we show how these genome conflicts have resulted in a finely tuned adjustment of the bacterial strain to each pure orthopteroid taxon, and the striking appearance of another, newly identified recombinant Wolbachia strain that only occurs in hybrid grasshoppers. We propose the existence of two superimposed hybrid zones: one organized by the grasshoppers, which overlaps with a second, bacterial hybrid zone. The two hybrid zones counterbalance one another and have evolved together since the origin of the grasshopper's hybrid zone.

\footnotetext{
Keywords: Wolbachia, Chorthippus parallelus, cytoplasmic incompatibility, MLST, bacterial recombination, hybrid zones
}

\section{INTRODUCTION}

Wolbachia is a well-known endosymbiotic alphaproteobacterium that is able to modify the reproduction (and, in some cases, the behavior) of infected individuals in diverse ways: male feminizing and killing, induced parthenogenesis, cytoplasmic incompatibility (CI), etc. These mechanisms all serve to promote Wolbachia's own, mainly maternal, transmission (Werren et al., 2008; Weinert et al., 2015; Jiggins, 2016). Initially, this infection was considered a kind of parasitism, but subsequent evidence revealed cases of neutral or even beneficial consequences for the host, involving the fecundity of infected individuals, resistance to other infections, etc. (Zug and Hammerstein, 2015; Makepeace and Gill, 2016). Since Wolbachia is a strictly cytoplasmic element, it has to establish a sophisticated dialogue not only with the organelles, but also with the nucleus, and even with other infectious organisms, such as the WO phage (LePage et al., 2017). This leads to frequently complex relations with the mitochondria, for example, which may sweep to cytonuclear incompatibilities (Henry and Newton, 2018). The reproductive barriers induced by this bacterium have led it to be considered a speciation agent under some circumstances (Bordenstein et al., 2001; Brucker and Bordenstein, 2012). It is also used as a biological agent against some pests of 
importance in agriculture and animal husbandry, and its role in some clinical and pathogenic processes cannot be ruled out (LePage and Bordenstein, 2013; Armoo et al., 2017; Ritchie et al., 2018).

Hybrid zones are places where organisms from different species, subspecies, races or, in general, any taxa, meet, interbreed and yield hybrid descendants. They are valuable models in the study of reproductive barriers, gene introgression, speciation and all kinds of evolutionary processes (Hewitt, 1988; Barton and Hewitt, 1989; Harrison, 1993), including those arising in response to climate change (Taylor et al., 2015).

The meadow grasshopper Chorthippus parallelus (Orthoptera) forms a Pyrenean hybrid zone that offers an outstanding model for the study of genetic divergence and processes of incipient speciation. During the last Pleistocene Ice Age, this organism retreated into a number of southern European refuges in the Iberian, Italian and Balkan peninsulas of the Mediterranean. Whilst the ice covered northern latitudes, genetic divergence in allopatry gave rise to two isolated subspecies: C. p. erythropus (Cpe) in Iberia, and C. p. parallelus (Cpp) in the rest of the continent. The ice finally melted after several cycles of advance and retreat, the high mountains of the Alps and Pyrenees being the last places from where it disappeared (Hewitt, 1993, 1996, 2001, 2011). During this time, both taxa kept evolving and diverging with respect to morphological, behavioral, electrophoretic and chromosomal traits (Butlin and Hewitt, 1985a,b; Bella et al., 2007). Genetic differentiation also occurs in certain mitochondrial and nuclear markers (Vazquez et al., 1994; Cooper et al., 1995; Lunt et al., 1998; Korkmaz et al., 2014).

Around 9,000 years ago (and thus 9,000 generations for this grasshopper) these incipient species met in restricted areas under $\sim 2,000 \mathrm{~m}$ (the altitudinal limit for this organism) that traverse the Pyrenees. There they formed a hybrid zone, which has been extensively studied from many perspectives over the last 30 years. After generations of mating, gene recombination, selection, etc., the natural hybrids ( $\mathrm{Cph}$ ) between $\mathrm{Cpp}$ and $\mathrm{Cpe}$ are viable and vigorous (Shuker et al., 2005). They inhabit restricted, narrow areas between the pure subspecies, which are currently too far away from each other to meet again. However, male F1 hybrids obtained in the laboratory are viable but sterile (Hewitt et al., 1987; Bella et al., 1990), in keeping with Haldane's Rule (Coyne, 2018 for a review).

These subspecies and their natural hybrids also differ in the strains of the endosymbiont Wolbachia that infect them (Zabal-Aguirre et al., 2010). This infection results in significant cytogenetic and genomic effects, and a partial additional reproductive barrier in the hybrid zone that is sustained by uni- and bidirectional CI (see below). This system constitutes an extraordinary model of coevolution of the genomes of all three taxa (pure Cpp and Cpe, and $\mathrm{Cph}$ ) with particular Wolbachia strains. The result is two overlapping hybrid zones: the aforementioned zone between the grasshopper subspecies, and, as we show here (see below), a second zone in Wolbachia, which is indicated by a specific pattern of infection of hybrid grasshoppers and the recombinant Wolbachia genomes that specifically appear in them. To our knowledge, this is the first report of a bacterial hybrid zone.

\section{THE INFECTION OF CHORTHIPPUS PARALLELUS BY WOLBACHIA}

Dillon et al. (2008) made the first report of infection of Cp by Wolbachia. It was soon followed by a cytological survey of Wolbachia in squashed and paraffin-embedded Cp tissues by $16 \mathrm{~S}$ rRNA and wsp surface protein in situ hybridization (whole-cell hybridization), which served to confirm the strict cytoplasmic distribution of the infection and the presence of bacteria in female and male gonadal tissues. However, during meiosis in males, there was an accumulation of Wolbachia in the pre-spermatic cells, whereby the bacteria aggregated at one pole until they disappeared in mature spermatic cells. Differences in bacterial density among tissues and individuals were also found (Martínez et al., 2009).

A study of around 4,700 individuals from $16 \mathrm{Cp}$ populations inside and outside the hybrid zone, using nested PCR with strainspecific $16 \mathrm{~S}$ rDNA primers to discriminate between bacterial strains showed that all the locations sampled were infected with Wolbachia, but with differences in infection type (B and $\mathrm{F}$ strains) and incidence between northern, hybrid and southern (Iberian) populations. This allowed us to distinguish three regional infection patterns associated with the distribution of pure and hybrid $\mathrm{Cp}$ individuals. A northern pattern characterized by a low level of B bacterial infection occurred in Cpp populations, while a southern pattern of a high level of infection (F or B or coinfected individuals) was characteristic of Cpe locations. In the hybrid zone, these patterns come together and give rise to a new, characteristic infection pattern that displays a remarkably high degree of co-infection with the two Wolbachia strains in hybrid individuals. No statistically significant differences in their proportions were found between the sexes in any of these locations, except for two populations in the hybrid zone that featured a lower than expected proportion of B infection and an excess of uninfected males compared with females (ZabalAguirre et al., 2010).

A further survey of the hybrid zone involving 110 crosses that were blind with respect to the presence or absence the strains of Wolbachia infection showed no evidence of any effects on female fecundity, except for a minor increase in the proportion of females infected by the F supergroup. However, the analysis of the parents and descendants using the nested-PCR system mentioned above confirmed the significant unidirectional CI, recorded as the relative reduction in embryo production ( $\mathrm{sh}$ ) in crosses involving B and F supergroups, with a sh of 0.355 and 0.286 , respectively. A CI with a weaker sh of 0.147 was noted in bidirectional crosses (Zabal-Aguirre et al., 2014). A preliminary study of the gonadal microbiota of $30 \mathrm{Cp}$ individuals from 13 populations, again inside and outside the hybrid zone, ruled out the possible action of other microbial agents that could induce these CIs, even revealing the presence of Spiroplasma, another bacterium that, in some cases, can disturb the reproduction of infected individuals (Martínez-Rodríguez et al., 2013). A further study of more than 200 individuals and 17 populations showed that Spiroplasma infects distinct C. parallelus populations, particularly frequently in those of the Balkan-Alps region. There is a lower frequency of infected individuals in 
the rest of continental Europe and the Iberian Peninsula, while no infection has been noticed in Southern Iberian populations. However, no interaction has been detected between the two endosymbionts, and there is no evidence of any influence of Spiroplasma on C. parallelus reproduction (Martínez-Rodríguez, 2013).

A recent analysis involving interannual frequencies of strains of Wolbachia across the Cp hybrid zone showed that they change significantly over geographical and temporal scales. By using consecutive years to estimate total Wolbachia strain fitness, and computer simulations to discount genetic drift and sampling error, the overall fitness pattern was found to show a negative frequency-dependent trend. This could be induced by natural selection, perhaps reinforced by other intrinsic or extrinsic (ecological) factors affecting the cytonuclear interaction of the infection (Martínez-Rodríguez et al., submitted).

The complexity of these interactions in our model is also indicated by the changes observed in the proportions of infected individuals in the populations during the host life cycle. Testing the infection frequencies several times in the same populations during the life cycle of these grasshoppers revealed significant differences at certain localities during the summer season. These were associated with a threshold temperature that appears to be lethal to the bacteria, but as a result it clearly influences the proportion of incompatible crosses over time in a given population and, consequently, the prevalence and spread of infection in subsequent generations (Martínez-Rodríguez et al., 2014).

The possible influence of Wolbachia on certain cytogenetic traits has also been analyzed in a pioneering way in this $\mathrm{Cp}$ model system. As expected, hybrid Cp grasshoppers were found to display a significantly higher level of abnormal spermatids (with respect to size, morphology, etc.) than pure Cpp and Cpe. However, when infected by Wolbachia, these Cph presented the highest percentage of abnormal spermatids, thereby demonstrating the synergy between the infection and the hybrid condition (Sarasa et al., 2013). As stated above, Wolbachia is maternally transmitted and progressively disappears from male meiocytes, as we showed in this system (Martínez et al., 2009), so the long-distance effect on the viability of the spermatids is remarkable. On the other hand, the same study (Sarasa et al., 2013) showed that Wolbachia significantly increases the number of chiasma in the meiocytes of infected males. These two situations (the increased frequencies of abnormal spermatids and chiasma in infected individuals) are good examples of a cytonuclear interaction, with the former, implying a degree of incompatibility. These results were also interpreted as secondary effects of a chromatin modification induced by Wolbachia under the proposed model of modification/rescue of the chromatin (Beckmann et al., 2017; LePage et al., 2017), and may explain the CI reported in these organisms.

The physical mapping by FISH in the chromosomes of $\mathrm{Cp}$ of certain fragments of the Wolbachia genome of both supergroups (B and F) that have been laterally transferred into its nuclear genome is an additional cytogenetic finding about this interaction between Cp and Wolbachia (Toribio-Fernández et al., 2017). Some of these insertions are subspecies-specific, while others are present in both subspecies. They must be considered as ancestral, given that they do indeed appear in uninfected individuals (Funkhouser-Jones et al., 2015). This additional example of cytonuclear dialogue between the endosymbiotic Wolbachia and the $\mathrm{Cp}$ genome indicates a close coevolution of the two genomes that we can summarize as specific biogeographical patterns of infection that fit well with the pure Cpp, Cpe or hybrid condition of the grasshoppers (specific bacterial strains preferentially infecting each taxa). This close relationship has to be old, given that certain fragments of the bacterial genome are now canonical parts of the nuclear genome of the grasshopper. However, during this time the genomes must have adapted to live together, resolving conflicts that after generations of counterbalance, still show mismatches like the uni- and bidirectional CI or the increase in frequency of abnormal spermatids in infected males.

\section{RESULTS}

\section{A Hybrid Bacterial Zone Overlapping That of Chorthippus parallelus}

A phylogenetic analysis based on Wolbachia $16 S$ rRNA gene sequences confirmed that $C$. parallelus are infected by at least four strains of the F supergroup and two strains of the B supergroup (Bella et al., 2010; Zabal-Aguirre et al., 2010; MartínezRodríguez et al., 2013). The existence of newly identified genetic markers allows us to characterize with greater precision the genetic diversity, potential recombination phenomena and the geographical distribution of Wolbachia through the Chorthippus parallelus hybrid zone (see Table S1).

\section{How Many Wolbachia Strains Infect C. parallelus?}

Six genes of Wolbachia (coxa, fbpa, ftsz, gatB, $h c p A$, and $w s p$ ) infecting 127 Chorthippus parallelus from 21 populations inside and outside the grasshopper hybrid zone (Table 1) were sequenced following the multilocus system typing (MLST system) proposed by Baldo et al. (2006b). As indicated above Wolbachia integrated sequences have been detected in $C$. parallelus nuclear genome (Funkhouser-Jones et al., 2015; Toribio-Fernández et al., 2017). However, different evidences rule out that they can introduce false positives in our analyses (see the Supplementary Material section for details).

Phylogenetic analyses of individual genes were carried out in order to characterize all alleles as belonging to the $\mathrm{F}$ or B supergroups (Figure 1; Figures S1-S11). Subsequent MSLT analysis allowed at least 33 different haplotypes or sequence types (ST) to be distinguished based on the combination of five loci. To confirm the other analyses Wsp gene was also included (see Figures S9, S10).

Nucleotide diversity and other characteristics are summarized in Table 2. In addition, recombination between $F$ and $B$ Wolbachia supergroups has been detected in some hybrid populations in the center of the Chorthippus hybrid zone (see below). Some recombinants have also been detected in the north of Spain in populations of this grasshopper characterized as hybrid on the basis of chromosomal markers (Bella et al., 2007). By contrast, recombination has not been detected in the pure 
TABLE 1 | Coordinates, altitude, individuals and nomenclature of the sampled populations of C. parallelus.

\begin{tabular}{|c|c|c|c|c|c|}
\hline Populations (as they appear in figures) & Population & Latitude & Longitude & Altitude (m) & $n$ \\
\hline \multicolumn{6}{|l|}{ PYRENEES-HYBRID ZONE } \\
\hline \multirow[t]{4}{*}{ HZ France } & Arudy (France): ARU & $43^{\circ} 06^{\prime} 01^{\prime \prime} \mathrm{N}$ & $0^{\circ} 26^{\prime} 38^{\prime \prime} \mathrm{W}$ & 411 & 5 \\
\hline & Gabas (France): GAB & $42^{\circ} 53^{\prime} 60^{\prime \prime} \mathrm{N}$ & $0^{\circ} 25^{\prime} 60^{\prime \prime} \mathrm{W}$ & 1,020 & 4 \\
\hline & L'Hermine (France): HER & $42^{\circ} 51^{\prime} 46.8^{\prime \prime} \mathrm{N}$ & $0^{\circ} 23^{\prime} 30.4^{\prime \prime} \mathrm{W}$ & 1,209 & 7 \\
\hline & Soques (France): SOQ & $42^{\circ} 20^{\prime} 08^{\prime \prime} \mathrm{N}$ & $0^{\circ} 23^{\prime} 52^{\prime \prime} \mathrm{W}$ & 1,396 & 3 \\
\hline Tourmont & Cabaña Tourmont (France): TOU & $42^{\circ} 49^{\prime} 11^{\prime \prime} \mathrm{N}$ & $0^{\circ} 24^{\prime} 21^{\prime \prime} \mathrm{W}$ & 1,625 & 4 \\
\hline Portalet & Portalet (Spain): POR/PORCRU & $42^{\circ} 48^{\prime} 03^{\prime \prime} \mathrm{N}$ & $0^{\circ} 24^{\prime} 54^{\prime \prime} \mathrm{W}$ & 1,780 & 17 \\
\hline $\mathrm{CM}$ & Corral de Mulas (Spain): CM & $42^{\circ} 47^{\prime} 09.4^{\prime \prime} \mathrm{N}$ & $0^{\circ} 23^{\prime} 34.4^{\prime \prime} \mathrm{W}$ & 1,569 & 9 \\
\hline Sallent & Sallent de Gállego (Spain): SAL & $42^{\circ} 45^{\prime} 57.5^{\prime \prime} \mathrm{N}$ & $0^{\circ} 20^{\prime} 33.9^{\prime \prime} \mathrm{W}$ & 1,343 & 5 \\
\hline Escarrilla & Escarrilla (Spain): ESC & $42^{\circ} 43^{\prime} 54.1^{\prime \prime} \mathrm{N}$ & $0^{\circ} 18^{\prime} 39.3^{\prime \prime} \mathrm{W}$ & 1,130 & 9 \\
\hline \multicolumn{6}{|l|}{ PYRENEES (OTHER) } \\
\hline \multirow[t]{3}{*}{ South-Pyrenees/Vielha } & Puerto del Cantó (Spain): PCAN & $42^{\circ} 22^{\prime} 12.9^{\prime \prime} \mathrm{N}$ & $1^{\circ} 14^{\prime} 11.7^{\prime \prime} \mathrm{E}$ & 1,725 & 6 \\
\hline & Muna (France): MUN & $42^{\circ} 53^{\prime} 53^{\prime \prime} N$ & $0^{\circ} 37^{\prime} 48.8^{\prime \prime} \mathrm{E}$ & 544 & 2 \\
\hline & Vielha (Spain): VIEL & $42^{\circ} 40^{\prime} 25.3^{\prime \prime} \mathrm{N}$ & $0^{\circ} 46^{\prime} 26.5^{\prime \prime} \mathrm{E}$ & 1,393 & 4 \\
\hline \multicolumn{6}{|c|}{ IBERIAN PENINSULA (CENTRAL MOUNTAINS) } \\
\hline \multirow[t]{2}{*}{ Center } & Navafría (Spain): NAV & $40^{\circ} 59^{\prime} 01.95^{\prime \prime} \mathrm{N}$ & $3^{\circ} 49^{\prime} 00.9^{\prime \prime} \mathrm{W}$ & 1,780 & 12 \\
\hline & Becedas (Spain): BEC & $40^{\circ} 24^{\prime} 18^{\prime \prime} \mathrm{N}$ & $5^{\circ} 38^{\prime} 17.2^{\prime \prime} \mathrm{W}$ & 1,091 & 3 \\
\hline \multicolumn{6}{|l|}{ IBERIAN PENINSULA (SOUTH) } \\
\hline Bubión & Bubión (Spain): BUB & $36^{\circ} 57^{\prime} 1.8^{\prime \prime} \mathrm{N}$ & $3^{\circ} 21^{\prime} 22.8^{\prime \prime} \mathrm{W}$ & 1,332 & 3 \\
\hline \multicolumn{6}{|l|}{ IBERIAN PENINSULA (NORTH) } \\
\hline \multirow[t]{2}{*}{ North } & Basque Country I (Spain): ALA & $42^{\circ} 58^{\prime} 41.4^{\prime \prime} \mathrm{N}$ & $2^{\circ} 44^{\prime} 19.7^{\prime \prime} \mathrm{W}$ & 625 & 6 \\
\hline & Basque Country II (Spain): URK & $43^{\circ} 13^{\prime} 59.1^{\prime \prime} \mathrm{N}$ & $2^{\circ} 29^{\prime} 22.3^{\prime \prime} \mathrm{W}$ & 211 & 6 \\
\hline \multicolumn{6}{|l|}{ EUROPE } \\
\hline \multirow[t]{2}{*}{ Alps } & Valdieri (Italy): VAL & $44^{\circ} 12^{\prime} 19.74^{\prime \prime} \mathrm{N}$ & $7^{\circ} 22^{\prime} 47.76^{\prime \prime} \mathrm{E}$ & 983 & 4 \\
\hline & Col de L'Arche (France): CLAR & $44^{\circ} 25^{\prime} 34.3^{\prime \prime} \mathrm{N}$ & $6^{\circ} 53^{\prime} 21.6^{\prime \prime} \mathrm{E}$ & 1,942 & 2 \\
\hline UK & Epping Forest (England): ENG & $51^{\circ} 39^{\prime} 36^{\prime \prime} \mathrm{N}$ & $0^{\circ} 3^{\prime} \mathrm{O}^{\prime \prime} \mathrm{E}$ & 102 & 3 \\
\hline Slovenia & Mokronog (Slovenia): SLO & $45^{\circ} 56^{\prime} 37.17^{\prime \prime} \mathrm{N}$ & $15^{\circ} 8^{\prime} 55.428^{\prime \prime} \mathrm{E}$ & $242 \mathrm{~m}$ & 12 \\
\hline
\end{tabular}

populations of the grasshopper, even though individuals may have been infected, or even co-infected, by B and F supergroup bacteria.

After discarding recombinant STs to avoid artifacts, the phylogenetic tree from concatenated sequences enabled at least 7 strains of Wolbachia belonging to the B supergroup and four strains of the $\mathrm{F}$ supergroup to be distinguished (Figure 2). This implies a high degree of genetic diversity, given that Wolbachia infects two nearby subspecies that have recently diverged (Hewitt, 1993). Furthermore, Wolbachia F strains in C. parallelus are closely related to one another. The genetic distance between the $F$ strains that infect both subspecies of Chorthippus parallelus is shorter than that between the F strains infecting Chorthippus and other insects. By contrast, B strains infecting Chorthippus are also closely related to other Wolbachia strains infecting other Orthoptera, including some species captured in the same populations as Chorthippus parallelus (Martínez-Rodríguez, 2013).

\section{What Is the Biogeographical Distribution of the Wolbachia Strains?}

Several analyses have shown important differences in the geographical distribution of the Wolbachia strains across the
C. parallelus populations, all of them showing in practice, the same scenario (Zabal-Aguirre et al., 2010; Martínez-Rodríguez, 2013; Martínez-Rodríguez et al., 2016, see also above). In general, the distribution of the F strains is aligned with the geographical distribution of the two grasshopper subspecies, that is, we find strains of F supergroup Wolbachia that are characteristic of Cpp and other strains that have been detected mainly in Cpe. In addition, several strains appear in the $C$. parallelus hybrid zone that have not previously been found in the pure populations. By contrast, we usually detect the same alleles of the B supergroup in Cpp and Cpe populations without distinction. However, we also noted the presence of new B alleles exclusive to Wolbachia that infect the hybrid grasshopper populations.

First, we analyzed all bacterial genetic markers individually. For instance, in the case of the $f b p A$ gene, fbpA-1, which belongs to supergroup F, was detected in pure populations from the center of the Iberian Peninsula and in the South Pyrenean populations (see Figure 3). By contrast, fbpA-5 (which is also a member of supergroup F) has mainly been described in pure populations of Cpp (rest of Europe) and in the pure Cpp population of Gabas, on the north side of the hybrid zone (Figure 3). It has also been detected in Bubión (Sierra Nevada, South Spain) and in some populations of the Cantabrian region (hybrid populations, according to Bella et al., 2007). FbpA-4 (also from the F 


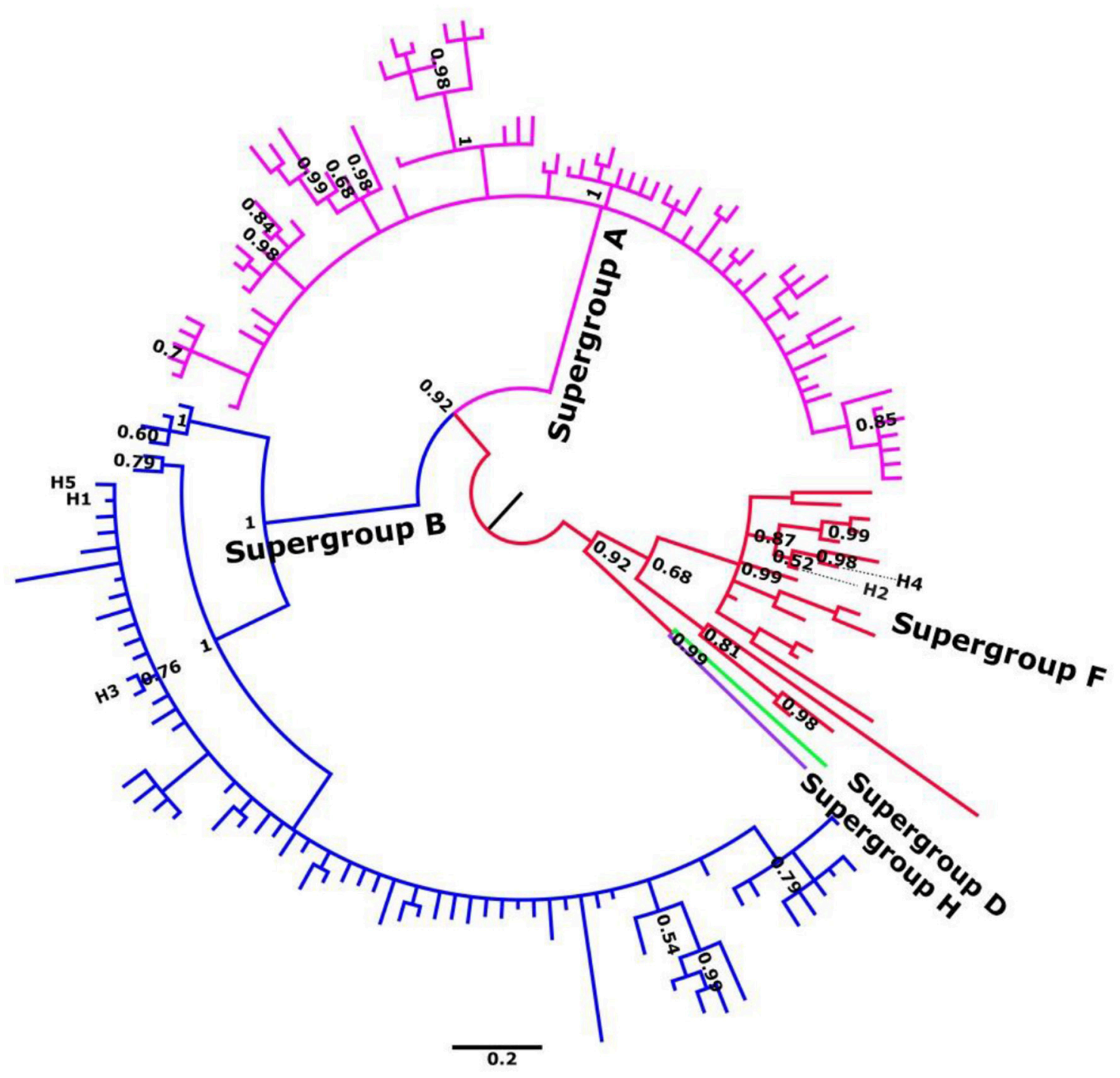

FIGURE 1 | Summary unrooted phylogenetic tree of gatb, obtained by Bayesian inference. Alleles described in C. parallelus are named $\mathrm{H} 1-\mathrm{H} 5$. Posterior probabilities are shown at the nodes. Sequence accession numbers are shown in Tables S3-S8.

supergroup) has been detected only in the Pyrenean populations of $C$. parallelus and in Cantabrian hybrid populations. In the case of supergroup B, fbpA-2 has been found in Cpp and Cpe populations. However, we have detected some new alleles in the hybrid populations of Sallent, Corral de Mulas and Portalet (see Figures 3, 4 and Supplementary Figures for details). Similar patterns have been observed for all the other genes analyzed (see Figures S12-S16).

Second, we considered all these markers simultaneously, according to the proposed MLST system, in order to gain a global vision of the geographical distribution of Wolbachia strains infecting pure and hybrid C. parallelus. We classified the different haplotypes or ST into five ST-complexes (each defined as a group of STs sharing a minimum of three alleles) (Figure 4, Figure S17). With respect to the F supergroup, the ST-1 complex has been detected in several pure C.p. parallelus populations and in some hybrid populations from the north of the hybrid zone. By contrast, the ST-5 complex, which also belongs to the F supergroup, has been detected in Cpe populations and in some hybrid populations in the south of the hybrid zone.

Considering the B supergroup, the ST2 complex is widely distributed in both subspecies, but the ST3 and ST4 complexes (which include some recombinants and B strains) have been detected mainly in hybrid populations.

A new genealogy-based analysis that infers Wolbachia microevolution from multilocus sequence data and from a consideration of recombination confirmed the genetic subdivisions in the strains of the F supergroup (Figure 5), while $\mathrm{B}$ strains were mainly grouped in the same clade. The genealogies also distinguished the recombinant strains that appear mostly in the grasshopper hybrid zone. The clades also support an association between the genetic and geographic data. 
TABLE 2 | Genetic diversity: S, total polymorphic positions; Eta, total frequency of mutations; Hap, frequency of haplotypes; Hd, Haplotype diversity; VarHd, Haplotype diversity variance; $\mathrm{Pi}$, nucleotide diversity; Theta, $4 \mathrm{Nu}$, where $\mathrm{N}$ is the effective population size, and $\mathrm{u}$ is the mutation rate per nucleotide (or per sequence) and per generation (Tajima, 1983; Nei, 1987).

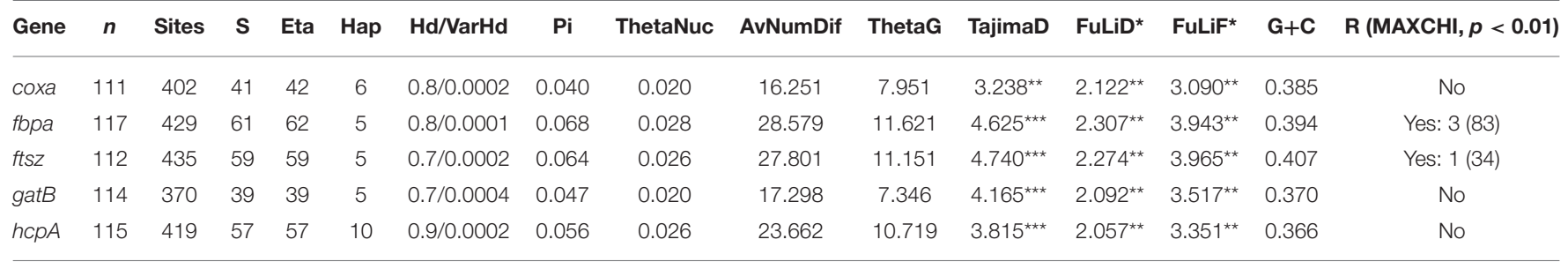

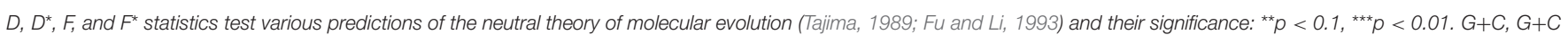
content; R, Recombination (MAXCHI, Maynard-Smith, 1992).

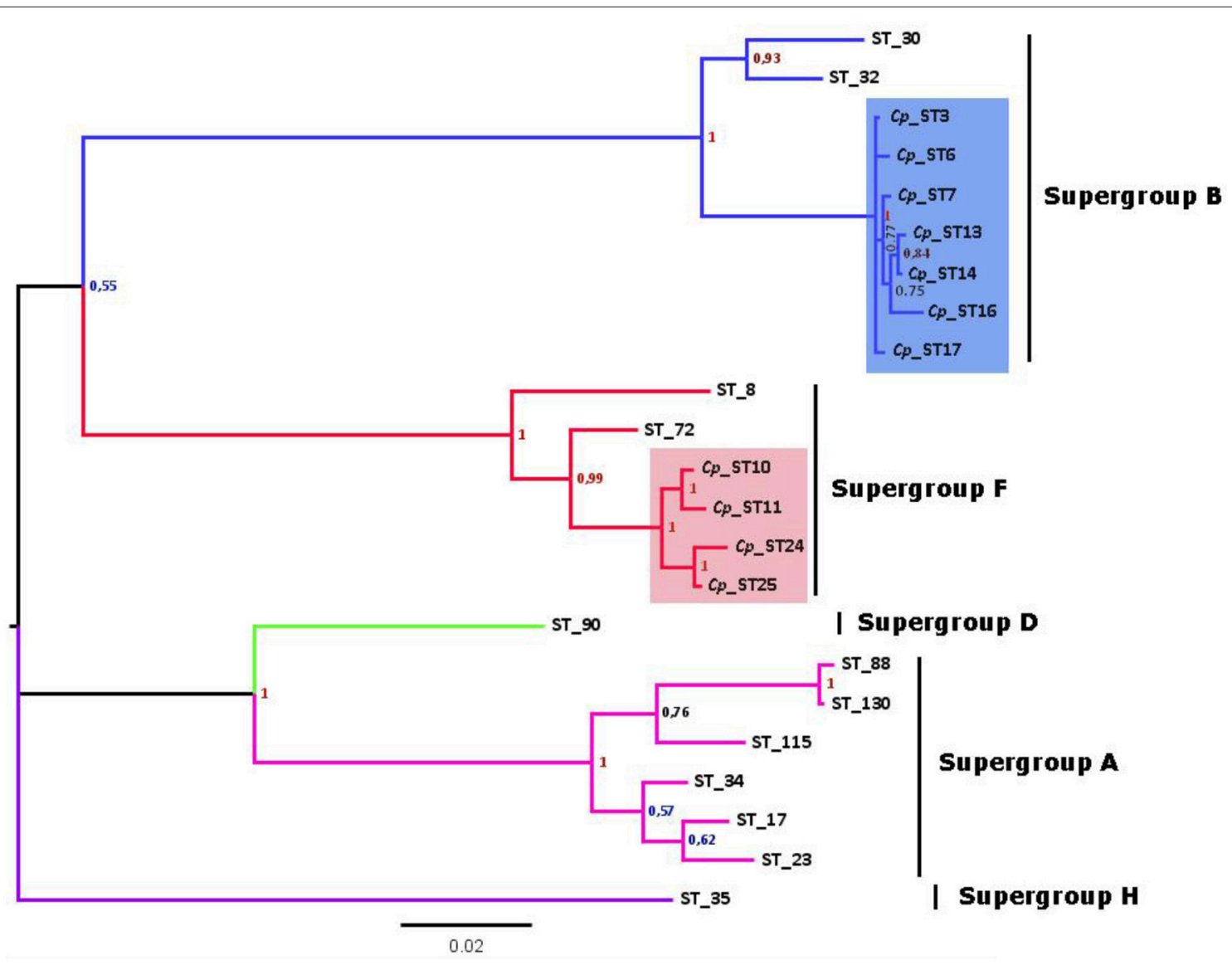

FIGURE 2 | Phylogenetic tree of Wolbachia STs detected in C. parallelus (marked as Cp, colored squares) excluding recombinants (see Figure 4) obtained by Bayesian inference. The alleles described in this grasshopper bear the prefix Cp_ST. All other STs, named according to the official nomenclature, are available in the MLST database (http://www.mlst.net/). Posterior probabilities are shown at the nodes.

Finally, the less differentiated isolates within geographic populations and the greater differentiation of those between geographic populations suggest isolation-by-distance between the bacterial F strains infecting the two grasshopper subspecies (with the exception of Bubión). An analysis of molecular variation (AMOVA) indicated a geographic division of the F supergroup into: (i) Central Iberian Peninsula and South Pyrenees populations, (ii) Pyrenean hybrid zone populations, (iii) populations on the French side of the hybrid zone, and (iv) non-Iberian populations from the rest of Europe and Bubión (in Spain) (Table 3). These results (except for those for $h c p A$ ) were also supported by a locus-by-locus AMOVA (Table S1) and an exact test of population differentiation (Rousset et al., 1992) (Table S2). In addition, Mantel tests confirmed that the genetic and geographic distances were correlated (rY1: $0.338, p=0.001)$. This correlation was stronger when the 


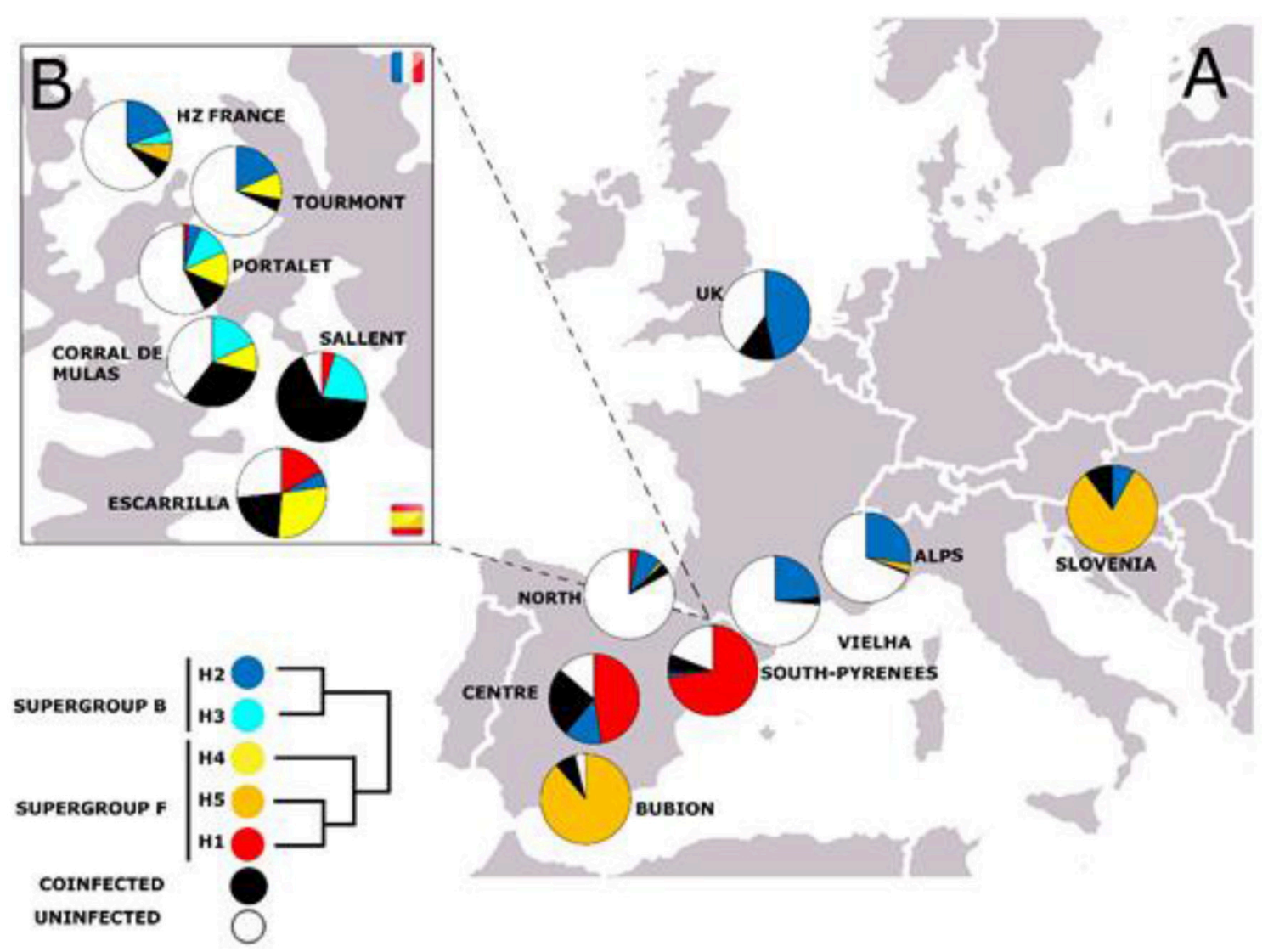

FIGURE 3 | (A) Geographical distribution of fbpA alleles in the C. paralle/us populations analyzed. The Pyrenean hybrid zone (Tena Valley, Huesca, Spain) is shown in detail in (B). See Table 1 for details.

Bubión data were excluded (rY1: $0.483, p=0.003$ ). This particular geographical distribution could be related to the biogeographical distribution of this grasshopper during the last glaciation, and enables us to infer the origin of Wolbachia infection in C. parallelus and its role in establishing the hybrid zone.

\section{DISCUSSION}

\section{The Co-divergence of the Host and Its Associated Bacteria: Wolbachia and Chorthippus parallelus Coevolution}

The prevalence of Wolbachia varies within and among nematode and arthropod taxa, and co-divergence events are known in nuclear and/or mitochondrial hosts genomes and their associated strains (Landmann et al., 2014; Lindsey and Stouthamer, 2017, but see Lefoulon et al., 2016), even including the parallel cospeciation of this bacterium with the common bedbug, Cimex lectularius (Balvín et al., 2018).

As described above, new data from the Wolbachia MLST system, obtained following Baldo et al. (2006b), confirmed the double infection by $\mathrm{F}$ and $\mathrm{B}$ supergroups and its distribution in C. parallelus. In addition, it revealed the great diversity at the supergroup level. First, these data confirmed the presence of two F bacterial types on both sides of the hybrid zone, as Zabal-Aguirre et al. (2010) suggested. This distribution largely coincides with the biogeography of $C$. parallelus. Second, the new data demonstrated a high degree of diversification of the Wolbachia strains infecting grasshopper hybrid populations, including the appearance of new alleles that had presumably arisen from recombination events between Wolbachia supergroups.

Wolbachia recombination events occur in grasshopper hybrid populations (in which the genomes of Cpp and Cpe met and hybridized), although the $\mathrm{F}$ and $\mathrm{B}$ supergroups are in contact in many other C. parallelus populations, and even coinfect individuals in pure and hybrid populations (Bella et al., 2010; Zabal-Aguirre et al., 2010, 2014). This biogeographical distribution has no simple explanation. It has been proposed that recombination processes between Wolbachia strains help the strains develop and adapt rapidly, which is important for their interaction with the host (Werren and Bartos, 2001; Jiggins, 2002). However, the recombination rate between strains is not constant, being respectively less and more common within and between subpopulations. Thus, those strains adapted to a particular host have limited levels of recombination compared with those that exceed the limit of the subpopulation, 


\begin{tabular}{|c|c|c|c|c|c|c|c|c|c|}
\hline $\begin{array}{c}\text { ST } \\
\text { Complex }\end{array}$ & ST & gatB & coxa & hсpA & $\mathrm{ftsZ}$ & fbpA & Type & $\mathrm{n}$ & Population \\
\hline ST-1 & 2 & 1 & 2 & 3 & 2 & 5 & $\mathrm{R}$ & 1 & HZ France \\
\hline ST-1 & 9 & 2 & 1 & 1 & 1 & 2 & $\mathrm{R}$ & 1 & HZ France \\
\hline ST-1 & 10 & 2 & 1 & 1 & 2 & 1 & $\mathrm{~F}$ & 2 & HZ France \\
\hline ST-1 & 11 & 2 & 1 & 3 & 2 & 5 & $\mathrm{~F}$ & 13 & Bubion (3), Alps (3) and Slovenia (7) \\
\hline ST-1 & 12 & 2 & 2 & 3 & 2 & 5 & $\mathrm{R}$ & 11 & HZ France \\
\hline ST-2 & 1 & 1 & 1 & 5 & 1 & 5 & $\mathrm{R}$ & 1 & South Pyrenees \\
\hline ST-2 & 3 & 1 & 2 & 5 & 1 & 2 & B & 4 & Escarrilla (1) and Centre (3) \\
\hline ST-2 & 5 & 1 & 5 & 3 & 1 & 2 & $\mathrm{R}$ & 1 & Vielha \\
\hline ST-2 & 6 & 1 & 5 & 5 & 1 & 2 & B & 10 & $\begin{array}{l}\text { Vielha (3), Slovenia (1), Alps(3), HZ } \\
\text { France (3) and England (3) }\end{array}$ \\
\hline ST-2 & 7 & 1 & 5 & 5 & 1 & 3 & B & 1 & HZ France \\
\hline ST-2 & 8 & 1 & 5 & 5 & 2 & 2 & $\mathrm{R}$ & 1 & South Pyrenees \\
\hline ST-2 & 17 & 3 & 5 & 5 & 1 & 2 & B & 4 & North \\
\hline ST-2 & 26 & 4 & 5 & 4 & 1 & 2 & $\mathrm{R}$ & 1 & Escarrilla \\
\hline ST-3 & 13 & 3 & 2 & 2 & 1 & 3 & B & 2 & Sallent \\
\hline ST-3 & 14 & 3 & 2 & 4 & 1 & 3 & B & 3 & Sallent (2) and CM (1) \\
\hline ST-3 & 16 & 3 & 2 & 7 & 1 & 3 & B & 2 & $\mathrm{CM}$ \\
\hline ST-3 & 30 & 5 & 2 & 2 & 1 & 2 & $\mathrm{R}$ & 1 & Portalet \\
\hline ST-3 & 32 & 5 & 6 & 7 & 1 & 2 & $\mathrm{R}^{*}$ & 1 & Tourmont \\
\hline ST-4 & 22 & 4 & 3 & 9 & 3 & 3 & $\mathrm{R}$ & 1 & Portalet \\
\hline ST-4 & 27 & 4 & 6 & 6 & 3 & 3 & $\mathrm{R}$ & 1 & Portalet \\
\hline ST-4 & 29 & 4 & 6 & 7 & 3 & 3 & $\mathrm{R}$ & 1 & Portalet \\
\hline ST-4 & 31 & 5 & 3 & 7 & 3 & 3 & $\mathrm{R}^{*}$ & 1 & Portalet \\
\hline ST-4 & 33 & 5 & 6 & 7 & 3 & 3 & $\mathrm{R}^{*}$ & 1 & Portalet \\
\hline ST-5 & 4 & 1 & 4 & 8 & 4 & 1 & $\mathrm{R}$ & 1 & Escarrilla \\
\hline ST-5 & 15 & 3 & 2 & 6 & 5 & 3 & $\mathrm{R}$ & 1 & $\mathrm{CM}$ \\
\hline ST-5 & 18 & 4 & 2 & 6 & 5 & 3 & $\mathrm{R}$ & 1 & $\mathrm{CM}$ \\
\hline ST-5 & 19 & 4 & 2 & 6 & 5 & 4 & $\mathrm{R}$ & 3 & $\mathrm{CM}(2)$ and Portalet (1) \\
\hline ST-5 & 20 & 4 & 2 & 9 & 5 & 4 & $\mathrm{R}$ & 1 & Tourmont \\
\hline ST-5 & 21 & 4 & 3 & 9 & 2 & 4 & $\mathrm{R}$ & 3 & Portalet (2) and Tourmont (1) \\
\hline ST-5 & 23 & 4 & 4 & 6 & 4 & 4 & $\mathrm{R}$ & 3 & Escarrilla (2) and CM (1) \\
\hline ST-5 & 24 & 4 & 4 & 6 & 5 & 4 & $\mathrm{~F}$ & & $\begin{array}{l}\text { Escarrilla ( } 3 \text { ) and CM (1) } \\
\text { Centre (6), South Pyrenees (5) and }\end{array}$ \\
\hline ST-5 & 25 & 4 & 4 & 8 & 5 & 1 & $\mathrm{~F}$ & 12 & Sallent (1) \\
\hline ST-5 & 28 & 4 & 6 & 6 & 5 & 4 & $\mathrm{R}$ & 5 & Portalet \\
\hline
\end{tabular}

FIGURE 4 | Wolbachia ST-complexes and allelic profiles described in C. parallelus. Note the classification in three groups: those assigned to supergroups F and B strains ("F" and "B," respectively) and those in which possible recombination events between these supergroups were observed ("R"). Individuals with no clear assignation are marked as $R^{*}$. Alleles belonging to the $F$ supergroup (see Figure $\mathbf{1}$ and Figures S2-S6) are marked in red, while alleles belonging to the B supergroup are marked in blue. STs detected in only one individual should be interpreted with caution, even if the alleles appear in more than one sample. The name of the population and the number of individuals (parenthesis) detected in each population are also indicated. 


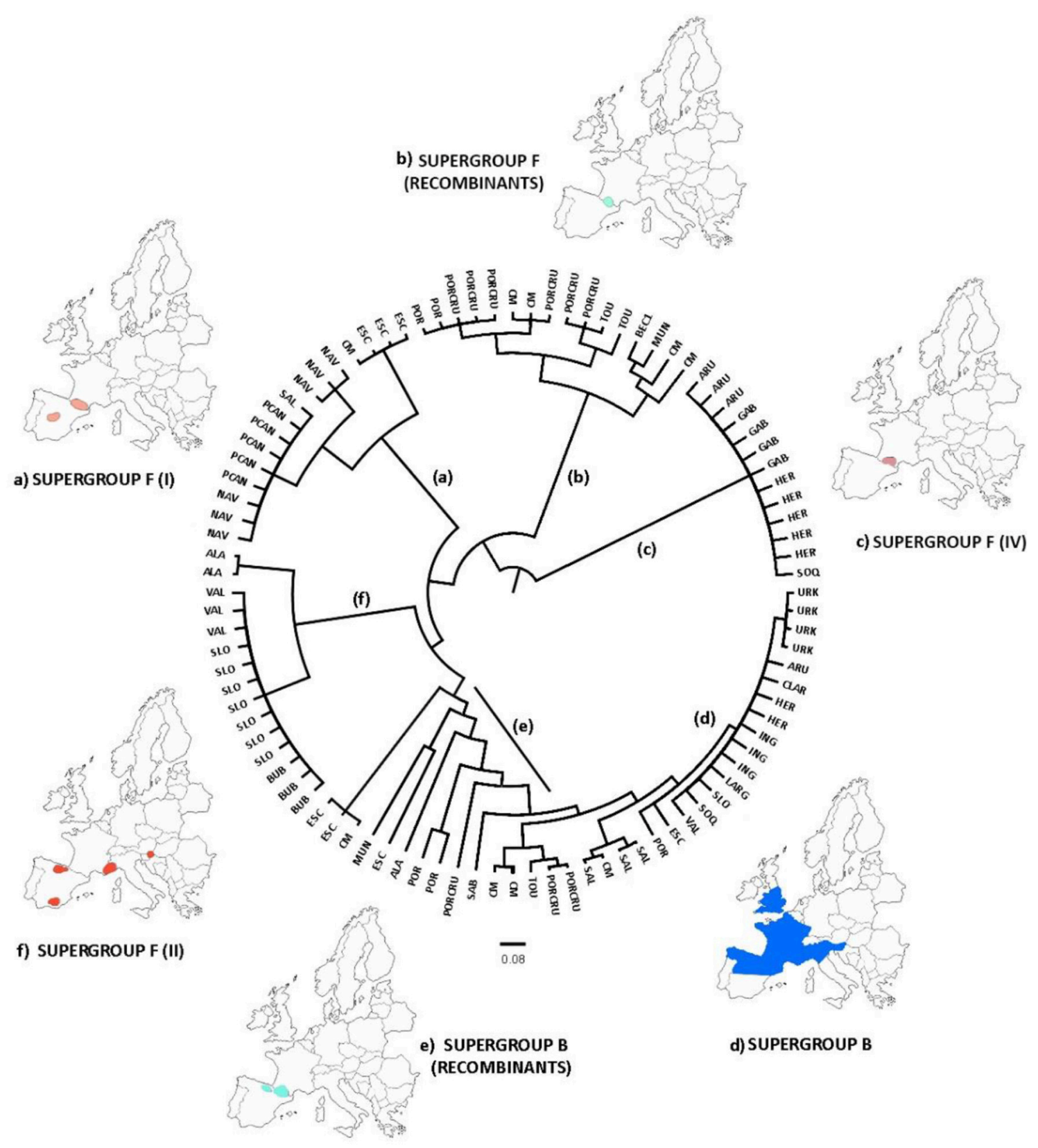

FIGURE $\mathbf{5}$ | ClonalFrame genealogy. Maps indicate the approximate location of the samples assigned to the major clades, classified with respect to their corresponding F or B supergroup. The analysis distinguished three major clades of supergroup F (A,C,F), one clade belonging to supergroup B (D), and several recombinant strains (B,E). This pattern was consistent with our previous analyses. Acronyms are listed in Table 1.

for example, by coming into contact with another host. These would have higher rates of recombination (Klasson et al., 2009). This hypothesis could explain the distribution of Wolbachia in the C. parallelus hybrid zone. After thousands of generations of coevolution between Wolbachia strains and pure host genomes, the formation of the hybrid zone placed the Wolbachia strains in contact with a new host genome (the hybrid genome) and accelerated the recombination process. This might explain why our analysis exclusively detects recombining strains (bacterial hybrid strains) that infect grasshopper hybrid populations.

In addition, we do not know the effect of recombination on the bidirectional CI between strains. Recombination could reduce it, or maybe favor the appearance of a new, mixed bacterial strain because of the host's genetic background in this area, in contrast to the pure populations on both sides of the Pyrenees. Further studies should be carried out to confirm this, but we note the smaller 
TABLE 3 | Analysis of molecular variance (AMOVA) from five MLST genes for the F supergroup of Wolbachia infecting different populations of C. parallelus.

\begin{tabular}{|c|c|c|c|c|}
\hline Source of variation & $d f$ & Sum of squares & Variance component & Percentage of variation \\
\hline Between groups & 3.00 & 820.69 & 13.60 & 39.80 \\
\hline Between populations within groups & 9.00 & 305.51 & 4.53 & 13.25 \\
\hline Between individuals within populations & 53.00 & 850.90 & 16.05 & 46.96 \\
\hline Total & 65.00 & 1977.11 & 34.19 & \\
\hline Indels: & Value & $\boldsymbol{P}$ & & \\
\hline$F_{\mathrm{SC}}$ & 0.220 & $<0.0001$ & & \\
\hline$F_{\mathrm{st}}$ & 0.530 & $<0.0001$ & & \\
\hline$F_{\mathrm{ct}}$ & 0.397 & $<0.0001$ & & \\
\hline
\end{tabular}

relative reduction in embryo production in the bidirectional crosses in the hybrid zone (Zabal-Aguirre et al., 2014; see above).

\section{Origin of Wolbachia Infection in C. parallelus and Its Effects on the Origin of the Hybrid Zone}

The new genetic data presented here help us infer the origin of Wolbachia infection in C. parallelus, and its role in the dynamics of the hybrid zone. Previous studies showed that the grasshopper subspecies diverged as a result of their geographic isolation in allopatry (Hewitt, 1993, 1999, 2001, 2011; Serrano et al., 1996) during the last glaciation. Recent cytogenetic data suggest that bacterial $\mathrm{F}$ strains and the ancestral $\mathrm{C}$. parallelus came into contact before the hybrid zone was formed (ToribioFernández et al., 2017). In addition, the phylogeographical distribution of Wolbachia suggests a strong correlation between Wolbachia and its host's biogeography. First, each subspecies of $C$. parallelus is infected mainly by a specific $\mathrm{F}$ strain of Wolbachia (Figure 6). Second, both F strains, which infect the two grasshopper subspecies, are more closely related than are other F strains that infect other hosts (Baldo et al., 2006a, 2007), as our phylogenetic analysis confirmed. So, even if co-divergence from allopatric hosts is apparently less common than horizontal transmission from other species (Raychoudhury et al., 2009), all the data suggest that $\mathrm{F}$ strains co-diverge with $C$. parallelus during host isolation. After the retreat of the ice, grasshopper populations from the Iberian Peninsula colonized the Pyrenees, meeting Cpp coming from the Balkans, as suggested by Lunt et al. (1998). Genetic incompatibilities between the host and bacterium accumulated during the divergence, together with the phenomenon of unidirectional IC, thereby influencing the formation of the current grasshopper hybrid zone. By contrast, the origin of the current $\mathrm{F}$ infection in Bubión is not known. The presence of the same strain that we detected in other European populations, as well as some exclusive cytogenetic markers (Bella et al., 2007), is intriguing, and more analyses are required to develop a hypothesis.

By contrast, the B supergroup could have been recently acquired as a result of rapid expansion of the infection from other taxa (horizontal transmission). In fact, further data have revealed closely related $\mathrm{B}$ strains in other orthopteroids that share the habitat with C. parallelus (Martínez-Rodríguez, 2013). This hypothesis is also supported by the homogeneity of the bacterial B strains located in distant populations, as well as the estimates of divergence between the strains detected in the hybrid zone and the rest of Europe. In addition, the lack of B infection in some populations, like Bubión in southern Spain, also suggests a recent spread of infection from continental Europe: the isolation of these populations and their geographical location has not yet resulted in an established infection. Loss of an ancestral B infection in this population seems less plausible to us, given the strain's aforementioned homogeneity.

Our results indicate that Wolbachia was present in the Chorthippus hybrid zone, where it has exerted its influence since the zone originated. This is therefore a relevant factor to be considered in the study of this model of incipient speciation.

\section{OVERLAPPING ORTHOPTEROID AND BACTERIAL HYBRID ZONES?}

Our data suggest the existence of a bacterial hybrid zone that is superimposed on the grasshopper's hybrid zone. The two zones would obviously be dynamically dependent, maintained by a delicate balance of multiple interactions. We are reminded that the C. parallelus hybrid zone was originally described as a secondary contact zone, maintained by the balance between dispersal and the presumed reduced fitness of the natural hybrids. This is supported by the close adherence to Haldane's rule (whereby heterogametic males are sterile) of F1 laboratory hybrids of pure individuals of the two subspecies, their mating behavior and the homogamy detected in studies of female sperm preference (Shuker et al., 2005). In the presumed genomic conflict between the two grasshopper subspecies, Wolbachia plays an additional role in reinforcing the reproductive barrier between them, as demonstrated by the unidirectional and bidirectional CI that it induces in field-collected hybrids (ZabalAguirre et al., 2014) and the increase in abnormal spermatid production (Sarasa et al., 2013). All of this reveals a complex scenario of specific coevolution of the endosymbiont and its host in continental Europe (pure C.p. parallelus), Iberia (pure C.p. erythropus) and the hybrid zone (hybrid C. parallelus), whereby each area and organism displays peculiarities and specific coadaptations. For this system to function successfully, 
A

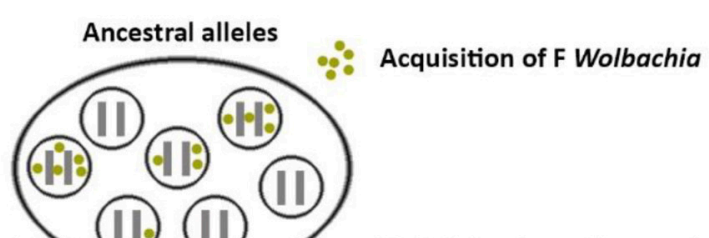

Allele 1 is selected in population 1

Allele 2 is selected in population 2
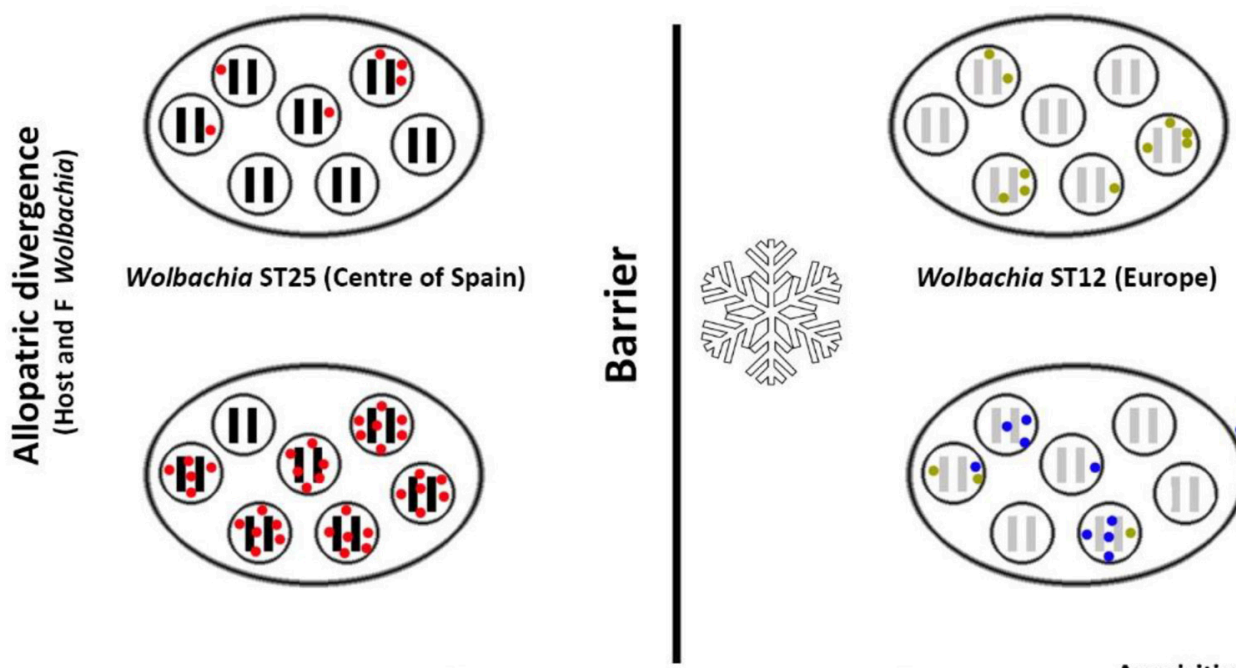

Wolbachia ST12 (Europe)
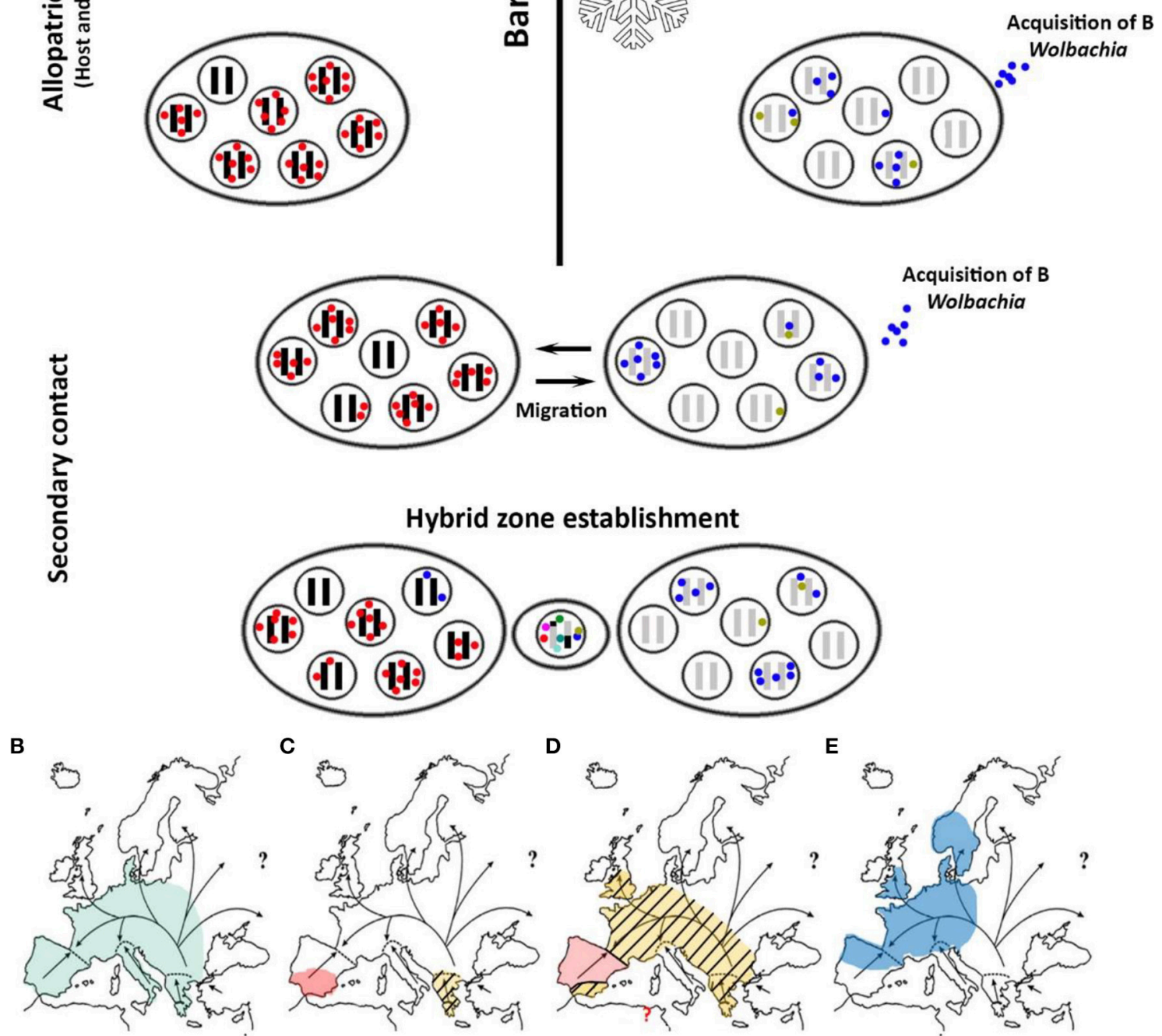

FIGURE 6 | (A) Proposed hypothesis for the origin of Wolbachia infection in C. paralle/us. Each ellipse represents a population. Inner circles represent individuals. Black and gray bars indicate the host genome, while the colored dots show the bacterial type infecting the individual. The hybrid zone would be established simultaneously with the appearance of recombinant genomes in the host, and considerable bacterial diversity, induced by recombination. (B) Spatial representation of the expansion of the infection: the arrows indicate the population expansion of C. parallelus (modified from Hewitt, 2001) after the retreat of the glacial ice. Before the last glaciation the infection of Wolbachia by the F supergroup was homogeneous. (C) During the last glaciation, C. paralle/us and F Wolbachia diverged in allopatry. (D) After the ice disappeared, the pattern of expansion of the F infection coincided with that of the migration of its host. (E) Recently, B infection has been transmitted (also horizontally) in various European populations. 
several processes need to be involved, including genome shock. Genome hybridization could accelerate changes at the genetic and epigenetic levels, and we cannot rule out the possibility that these may affect the endosymbiont-host relationship.

Overall, by simultaneously considering the host and endosymbiont genomes, our findings suggest the existence of three main genetic groups: Cpe-IberianWolF, Cpp-WolB, and Hybrid-EuropeanWolF. Preliminary microsatellite data confirm the high degree of genetic $C$. parallelus diversification in hybrid populations and differentiate the same three population groups in the hybrid zone (Sarasa, 2013). Wolbachia strains coincide with this distribution, including the new hybrid bacterial strains that exclusively infect hybrid grasshopper populations, thereby indicating the co-divergence and coevolution of the bacterial strains with their hosts, but also the result of their genomic conflict and the delicate balance of cytonuclear compatibilities and incompatibilities (Bhattacharya and Newton, 2017).

\section{DATA AVAILABLITY STATEMENT}

DNA sequences: GenBank database under accession numbers KM078849-KM078883.

\section{AUTHOR CONTRIBUTIONS}

All authors listed have made a substantial, direct and intellectual contribution to the work, and approved it for publication.

\section{REFERENCES}

Armoo, S., Doyle, S. R., Osei-Atweneboana, M. Y., and Grant, W. N. (2017). Significant heterogeneity in Wolbachia copy number within and between populations of Onchocerca volvulus. Parasit. Vectors 10:188. doi: 10.1186/s13071-017-2126-4

Baldo, L., Bordenstein, S. R., Wernegreen, J. J., and Werren, J. H. (2006a). Widespread recombination throughout Wolbachia genomes. Mol. Biol. Evol. 23, 437-449. doi: 10.1093/molbev/msj049

Baldo, L., Hotopp, J. C. D., Jolley, K. A., Bordenstein, S. R., Biber, S. A., Choudhury, R. R., et al. (2006b). Multilocus sequence typing system for the endosymbiont Wolbachia pipientis. App. Environ. Microbiol. 72, 7098-7110. doi: 10.1128/AEM.00731-06

Baldo, L., Prendini, L., Corthals, A., and Werren, J. H. (2007). Wolbachia are present in Southern African scorpions and cluster with supergroup F. Curr. Microbiol. 55, 367-373. doi: 10.1007/s00284-007-9009-4

Balvín, O., Roth, S., Talbot, B., and Reinhardt, K. (2018). Co-speciation in bedbug Wolbachia parallel the pattern in nematode hosts. Sci. Rep. 8:8797. doi: 10.1038/s41598-018-25545-y

Barton, N. H., and Hewitt, G. M. (1989). Adaptation, speciation and hybrid zones. Nature 341, 497-503. doi: 10.1038/341497a0

Beckmann, J. F., Ronau, J. A., and Hochstrasser, M. (2017). A Wolbachia deubiquitylating enzyme induces cytoplasmic incompatibility. Nat. Microbiol. 2:17007. doi: $10.1038 / \mathrm{nmicrobiol} .2017 .7$

Bella, J. L., Hewitt, G. M., and Gosalvez, J. (1990). Meiotic imbalance in laboratoryproduced hybrid males of Chorthippus parallelus parallelus and Chorthippus parallelus erythropus. Gen. Res. 56, 43-48. doi: 10.1017/S001667230002886X

Bella, J. L., Martínez-Rodríguez, P., Arroyo-Yebras, F., Bernal, A., Sarasa, J., Fernández-Calvín, B., et al. (2010). Wolbachia infection in the Chorthippus parallelus hybrid zone: evidence for its role as a reproductive barrier. J. Orthopt. Res. 19, 205-212. doi: 10.1665/034.019.0206

\section{FUNDING}

This work has been supported by the Spanish MINECO I + D+i grants CGL2009-08380/BOS and CGL2012-35007 with the collaboration of Chromacell.

\section{ACKNOWLEDGMENTS}

We are grateful to the authorities that gave us permission to collect the specimens analyzed here: Parc National des Pyrenèes, Parque Nacional de Sierra Nevada, Comunidad Autónoma de Madrid, Comunidad Autónoma de Aragón, Comunidad Autónoma de Castilla y León, Parc National du Mercantour Alpes-Maritimes, etc. Dr. P. L. Mason (University of Glasgow, UK) helped us with the manuscript and Dr. J. R. Dagley and Dr. R. Kostanjšek kindly provided the individuals from the Epping Forest (UK) and Mokronog (Slovenia), respectively. We also thank other members of our HYZO group in the Universidad Autónoma de Madrid, who helped with insect collection and handling, or contributed to discussions about our study. Some contents of this manuscript have been released as a pre-print as Martínez-Rodríguez et al. (2016).

\section{SUPPLEMENTARY MATERIAL}

The Supplementary Material for this article can be found online at: https://www.frontiersin.org/articles/10.3389/fgene. 2018.00604/full\#supplementary-material

Bella, J. L., Serrano, L., Orellana, J., and Mason, P. L. (2007). The origin of the Chorthippus parallelus hybrid zone: chromosomal evidence of multiple refugia for Iberian populations. J. Evol. Biol. 20, 568-576. doi: 10.1111/j.1420-9101.2006.01254.x

Bhattacharya, T., and Newton, I. L. G. (2017). Mi casa es su casa: how an intracellular symbiont manipulates host biology. Environ. Microbiol. doi: 10.1111/1462-2920.13964. [Epub ahead of print].

Bordenstein, S. R., O'Hara, F. P., and Werren, J. H. (2001). Wolbachia-induced incompatibility precedes other hybrid incompatibilities in Nasonia. Nature 409, 707-710. doi: 10.1038/35055543

Brucker, R. M., and Bordenstein, S. R. (2012). Speciation by symbiosis. Trends Ecol. Evol. 27, 443-451. doi: 10.1016/j.tree.2012.03.011

Butlin, R. K., and Hewitt, G. M. (1985a). A hybrid zone between Chorthippus parallelus parallelus and Chorthippus parallelus erythropus (Orthoptera:Acrididae): behavioural characters. Biol. J. Linn. Soc. 26, 287-299. doi: 10.1111/j.1095-8312.1985.tb01637.x

Butlin, R. K., and Hewitt, G. M. (1985b). A hybrid zone between Chorthippus parallelus parallelus and Chorthippus parallelus erythropus (Orthoptera, Acrididae) - morphological and electrophoretic characters. Biol. J. Linn. Soc. 26, 269-285. doi: 10.1111/j.1095-8312.1985.tb01636.x

Cooper, S. J. B., Ibrahim, K. M., and Hewitt, G. M. (1995). Postglacial expansion and genome subdivision in the European grasshopper Chorthippus parallelus. Mol. Ecol. 4, 49-60. doi: 10.1111/j.1365-294X.1995.tb00191.x

Coyne, J. A. (2018). Two rules of speciation revisited. Mol. Ecol. 27, 3749-3752. doi: $10.1111 / \mathrm{mec} .14790$.

Dillon, R. J., Webster, G., Weightman, A. J., Dillon, V. M., Blanford, S., and Charnley, A. K. (2008). Composition of Acridid gut bacterial communities as revealed by $16 \mathrm{~S}$ rRNA gene analysis. J. Invert. Pathol. 97, 265-272. doi: 10.1016/j.jip.2007.09.010

Fu, Y., and Li, W. (1993). Statistical tests of neutrality of mutations. Genetics 133, 693-709. 
Funkhouser-Jones, L. J., Sehnert, S. R., Martínez-Rodríguez, P., ToribioFernández, R., Pita, M., Bella, J. L., et al. (2015). Wolbachia co-infection in a hybrid zone: discovery of horizontal gene transfers from two Wolbachia supergroups into an animal genome. Peer J. 3: e1479. doi: 10.7717/peerj.1479

Harrison, R. G. (1993). Hybrid Zones and the Evolutionary Process. New York, NY: Oxford University Press.

Henry, L. P., and Newton, I. L. G. (2018). Mitochondria and Wolbachia titers are positively correlated during maternal transmission. Mol. Ecol. 27, 2634-2646. doi: $10.1111 / \mathrm{mec} .14700$

Hewitt, G. M. (1988). Hybrid zones -natural laboratories for evolutionary studies. Trends Ecol. Evol. 3, 158-167. doi: 10.1016/0169-5347(88)90033-X

Hewitt, G. M. (1993). "After the ice - parallelus meets erythropus in the Pyrenees," in Hybrid Zones and the Evolutionary Process, ed R. G. Harrisonpp (Oxford: Oxford University Press), 140-164.

Hewitt, G. M. (1996). Some genetic consequences of ice ages, and their role in divergence and speciation. Biol. J. Linn. Soc. 58, 247-276. doi: 10.1111/j.1095-8312.1996.tb01434.x

Hewitt, G. M. (1999). Post-glacial re-colonization of European biota. Biol. J. Linn. Soc. 68, 87-112. doi: 10.1111/j.1095-8312.1999.tb01160.x

Hewitt, G. M. (2001). Speciation, hybrid zones and phylogeography - or seeing genes in space and time. Mol. Ecol. 10, 537-549. doi: 10.1046/j.1365-294x.2001.01202.x

Hewitt, G. M. (2011). Quaternary phylogeography: the roots of hybrid zones. Genetica 139, 617-638. doi: 10.1007/s10709-011-9547-3

Hewitt, G. M., Butlin, R. K., and East, T. M. (1987). Testicular dysfunction in hybrids between parapatric subspecies of the grasshopper Chorthippus parallelus. Biol. J. Linn. Soc. 31, 25-34. doi: 10.1111/j.1095-8312.1987.tb01 978.x

Jiggins, F. M. (2002). The rate of recombination in Wolbachia bacteria. Mol. Biol. Evol. 19, 1640-1643. doi: 10.1093/oxfordjournals.molbev.a004228

Jiggins, F. M. (2016). Open questions: how does Wolbachia do what it does? BMC Biol. 14:92. doi: 10.1186/s12915-016-0312-z

Klasson, L., Westberg, J., Sapountzis, P., Näslund, K., Lutnaes, Y., Darby, A. C., et al. (2009). The mosaic genome structure of the Wolbachia wRi strain infecting Drosophila simulans. Proc. Natl. Acad. Sci. U.S.A. 106, 5725-5730. doi: $10.1073 /$ pnas.0810753106

Korkmaz, E. M., Lunt, D. H., Çiplak, B., Degerli, N., and Başibüyük, H. H. (2014). The contribution of Anatolia to European phylogeography: the centre of origin of the meadow grasshopper, Chorthippus parallelus. J. Biogeogr. 41, 1793-1805. doi: $10.1111 /$ jbi.12332

Landmann, F., Foster, J. M., Michalski, M. L., Slatko, B. E., and Sullivan, W. (2014). Co-evolution between an endosymbiont and its nematode host: Wolbachia asymmetric posterior localization and AP polarity establishment. PLoS Negl. Trop. Dis. 8:e3096. doi: 10.1371/journal.pntd.00 03096

Lefoulon, E., Bain, O., Makepeace, B. L., d'Haese, C., Uni, S., Martin, C., et al. (2016). Breakdown of coevolution between symbiotic bacteria Wolbachia and their filarial hosts. Peer J. 4:e1840. doi: 10.7717/peerj.1840

LePage, D. P., Metcalf, J. A., Bordenstein, S. R., On, J., Perlmutter, J. I., Shropshire, J. D., et al. (2017). Prophage WO genes recapitulate and enhance Wolbachia-induced cytoplasmic incompatibility. Nature $543,243-247$. doi: 10.1038/nature21391

LePage, D. P., and Bordenstein, S. R. (2013). Wolbachia: can we save lives with a great pandemic? Trends Parasitol. 29, 385-393. doi: 10.1016/j.pt.2013. 06.003

Lindsey, A. R. I., and Stouthamer, R. (2017). The effects of outbreeding on a parasitoid wasp fixed for infection with a parthenogenesis-inducing Wolbachia symbiont. Heredity 119, 411-417. doi: 10.1038/hdy.2017.53

Lunt, D. H., Ibrahim, K. M., and Hewitt, G. M. (1998). mtDNA phylogeography and postglacial patterns of subdivision in the meadow grasshopper Chorthippus parallelus. Heredity 80, 633-641. doi: 10.1046/j.1365-2540.1998.00311.x

Makepeace, B. L., and Gill, A. C. (2016). "Wolbachia," in Rickettsiales. Biology, Molecular Biology, Epidemiology, and Vaccine Development, ed S. Thomas (Cham: Springer Nature).

Martínez, P., Del Castillo, P., and Bella, J. L. (2009). Cytological detection of Wolbachia in squashed and paraffin embedded insect tissues. Biotech. Histochem. 84, 347-353. doi: 10.3109/10520290902903381
Martínez-Rodríguez, P. (2013). Divergencia Inducida Por Wolbachia en la Zona híbrida de Chorthippus Parallelus (Orthoptera). PhD Thesis. Universidad Autónoma de Madrid.

Martínez-Rodríguez, P., Arroyo-Yebras, F., and Bella, J. L. (2016). Understanding Wolbachia acquisition and co-divergence of hosts and their associated bacteria: Wolbachia infection in the Chorthippus parallelus hybrid zone. BioRxiv 044784.

Martínez-Rodríguez, P., Granero-Belinchón, R., Arroyo-Yebras, F., and Bella, J. L. (2014). New insight into Wolbachia epidemiology: its varying incidence during the host life cycle can alter bacteria spread. Bull. Math. Biol. 76, 2646-2663. doi: 10.1007/s11538-014-0029-5

Martínez-Rodríguez, P., Hernández-Pérez, M., and Bella, J. L. (2013). Detection of Spiroplasma and Wolbachia in the bacterial gonad community of Chorthippus parallelus. Microb. Ecol. 66, 211-223. doi: 10.1007/s00248-0130226-z

Maynard-Smith, J. (1992). Analyzing the mosaic structure of genes. J. Mol. Evol. 34, 126-129.

Nei, M. (1987). Molecular Evolutionary Genetics. New York, NY: Columbia University Press.

Raychoudhury, R., Baldo, L., Oliveira, D. C. S. G., and Werren, J. H. (2009). Modes of acquisition of Wolbachia: horizontal transfer, hybrid introgression, and codivergence in the Nasonia species complex. Evolution 63, 165-183. doi: 10.1111/j.1558-5646.2008.00533.x

Ritchie, S. A., van den Hurk, A. F., Smout, M. J., Staunton, K. M., and Hoffmann, A. A. (2018). Mission accomplished? We need a guide to the 'post release' world of Wolbachia for Aedes-borne disease control. Trends Parasitol. 34, 217-226. doi: 10.1016/j.pt.2017.11.011

Rousset, F., Vautrin, D., and Solinag, M. (1992). Molecular-identification of Wolbachia, the agent of cytoplasmic incompatibility in Drosophila simulans, and variability in relation with host mitochondrial types. Proc. R. Soc. Lond. B Biol. Sci. 247, 163-168. doi: 10.1098/rspb.1992.0023

Sarasa, J. (2013). La zona híbrida Pirenaica de Chorthippus Parallelus Parallelus y Chorthippus Parallelus Erythropus (Orthoptera). PhD Thesis. Universidad Autónoma de Madrid.

Sarasa, J., Bernal, A., Fernández-Calvín, B., and Bella, J. L. (2013). Wolbachia induced cytogenetical effects as evidenced in Chorthippus parallelus (Orthoptera). Cytogenet. Genome Res. 139, 36-43. doi: 10.1159/000341572

Serrano, L., García de la Vega, C., Bella, J. L., López-Fernández, C., Hewitt, G. M., and Gosálvez, J. (1996). A hybrid zone between two subspecies of Chorthippus parallelus. X-chromosome variants through a contact zone. J. Evol. Biol. 9, 173-184. doi: 10.1046/j.1420-9101.1996.9020173.x

Shuker, D., King, T., Bella, J. L., and Butlin, R. K. (2005). "The genetic basis of speciation in a grasshopper hybrid zone," in Insect Evolutionary Biology, ed M. H. G. Fellowes and J. Roff (Wallingford, Oxon: CABI Publishing, Oxford University Press), 427-454.

Tajima, F. (1983). Evolutionary relationship of DNA sequences in finite populations. Genetics $105,437-460$.

Tajima, F. (1989). Statistical method for testing the neutral mutationhypothesis by DNA polymorphism. Genetics $123,585-595$.

Taylor, S. A., Larson, E. L., and Harrison, R. G. (2015). Hybrid zones: windows on climate change. Trends Ecol. Evol. 30, 398-406. doi: 10.1016/j.tree.2015.04.010

Toribio-Fernández, R., Bella, J. L., Martínez-Rodríguez, P., Funkhouser-Jones, L. J., Bordenstein, S. R., and Pita, M. (2017). Chromosomal localization of Wolbachia inserts in the genomes of two subspecies of Chorthippus parallelus forming a Pyrenean hybrid zone. Chrom. Res. 25, 215-225. doi: 10.1007/s10577-017-9557-9

Vazquez, P., Cooper, S. J. B., Gosálvez, J., and Hewitt, G. M. (1994). Nuclear DNA introgression across a Pyrenean hybrid zone between parapatric subspecies of the grasshopper Chorthippus parallelus. Heredity 73, 436-443. doi: 10.1038/hdy.1994.191

Weinert, L. A., Araujo-Jnr, E. V., Ahmed, M. Z., and Welch, J. J. (2015). The incidence of bacterial endosymbionts in terrestrial arthropods. Proc. R. Soc. B. Biol. Sci. 282, 1-6. doi: 10.1098/rspb.2015.0249

Werren, J. H., Baldo, L., and Clark, M. E. (2008). Wolbachia: master manipulators of invertebrate biology. Nat. Rev. Microbiol. 6, 741-751. doi: $10.1038 /$ nrmicro1969

Werren, J. H., and Bartos, J. D. (2001). Recombination in Wolbachia. Curr. Biol. 11, 431-435. doi: 10.1016/S0960-9822(01)00101-4 
Zabal-Aguirre, M., Arroyo, F., and Bella, J. L. (2010). Distribution of Wolbachia infection in Chorthippus parallelus populations within and beyond a Pyrenean hybrid zone. Heredity 104, 174-184. doi: 10.1038/hdy.20 09.106

Zabal-Aguirre, M., Arroyo, F., García-Hurtado, J., de la Torre, J., Hewitt, G. M., and Bella, J. L. (2014). Wolbachia effects in natural populations of Chorthippus parallelus from the Pyrenean hybrid zone. J. Evol Biol. 27, 1136-1148. doi: $10.1111 /$ jeb.12389

Zug, R., and Hammerstein, P. (2015). Bad guys turned nice? A critical assessment of Wolbachia mutualisms in arthropod hosts. Biol. Rev. Soc. 90, 89-111. doi: 10.1111/brv.12098
Conflict of Interest Statement: The authors declare that the research was conducted in the absence of any commercial or financial relationships that could be construed as a potential conflict of interest.

Copyright (๑) 2018 Martínez-Rodríguez and Bella. This is an open-access article distributed under the terms of the Creative Commons Attribution License (CC BY). The use, distribution or reproduction in other forums is permitted, provided the original author(s) and the copyright owner(s) are credited and that the original publication in this journal is cited, in accordance with accepted academic practice. No use, distribution or reproduction is permitted which does not comply with these terms. 